\title{
Anxiety, Self-Efficacy, and the Role of Study Abroad
}

\section{Marshall Klassen \\ Kanazawa Seiryo University}

\section{Nicholas Marx}

Ritsumeikan University

\section{Reference Data:}

Klassen, M., \& Marx, N. (2020). Anxiety, self-efficacy, and the role of study abroad. In P. Clements, A. Krause, \& R. Gentry (Eds.), Teacher efficacy, learner agency. Tokyo: JALT.

https://doi.org/10.37546/JALTPCP2019-25

Research has shown that foreign language classroom anxiety often has a debilitating effect on language learners' self-perceptions (Horwitz, 2001). Self-efficacy is also a notable concept in relation to learners' self-perceptions of their ability to complete tasks (Bandura, 1982). Relating experiences of anxiety in the classroom with self-efficacy, in this study we looked at correlations between self-efficacy and foreign language anxiety and changes in these affective factors for university English learners. A pretest-posttest methodology was utilized before and after the participants studied abroad. Negative correlations were found between language anxiety and self-efficacy across both tests. In addition, significant findings from the individual test could be seen before and after studying abroad, showing in what ways study abroad may affect learner's anxiety and self-efficacy.

先行研究では、外国語教室不安が言語学習者の自己認識を衰弱させる効果があることを示している(Horwitz，2001)。ま た、自己効力感は、自分自身がタスクをどれだけ遂行できるかの自己認識に関連している注目すべき概念である(Bandura, 1982)。本研究では、外国語の不安と自己効力感を関連付けて、大学での英語学習者に対する感情的要因の変化を調べた。

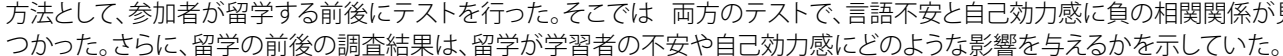

anguage learner beliefs in their own competence can be influenced by a number of factors both inside and outside the classroom. As an increasing number of students are engaging in study-abroad programs, these factors may shape their experiences and their learning trajectories (Nagahashi, 2007). Students who study abroad are expected to express themselves in a foreign language in an unfamiliar place, which can be threatening to self-image (Young, 1999).

Language learner perceptions are often influenced by affective factors such as anxiety and self-efficacy, which are exacerbated by stressful situations such as study abroad.

Although both of these factors have been independently studied in the Japanese context, not many have looked at how these two affective factors could be related. Foreign language anxiety is defined as "a distinct complex of self-perceptions, beliefs, feelings and behaviors related to classroom language learning arising from the uniqueness of the language learning process" (Horwitz, Horwitz, \& Cope, 1986, p. 128). Students in a foreign language learning environment are expected to participate within an unfamiliar medium of communication, which can affect self-perceptions. Concerning self-efficacy, the perception of one's own ability to accomplish tasks (Bandura, 1982) is another factor of great importance due to its relationship to motivation, commitment, and selfregulation of learning strategies (Wang, 2014).

In this research, both self-efficacy and foreign language anxiety are part of an inquiry into Japanese university students who were studying abroad during their first year. This quantitative research explores the potential relationship between self-efficacy and foreign language anxiety with pre- and post-study-abroad results using the Foreign Language Classroom Anxiety Scale (Horwitz et al., 1986; Yashima et al., 2009) and the Questionnaire of English Self-Efficacy (Wang, 2004). 


\section{Literature Review}

\section{Study Abroad}

Japanese universities have been increasingly promoting study abroad in accordance with the aspirations of the Ministry of Education, Culture, Sports, Science and Technology (MEXT), pushed by the creation of the MEXT Tobitate! Ryugaku [Leap for Tomorrow! Study Abroad] Japan (2014) initiative. This initiative provides educational institutes with support to continually increase the number of students abroad per year with the intent of acquiring higher levels of language acquisition and abilities in academic English. English education programs, for example, will require future English teachers to not only study English grammar and teaching but also have international experience, such as studying abroad (English teachers to study abroad, 2013). Despite the fact that there is a push for students to participate in study abroad, students still feel unsure and anxious due to pressures such as searching for a job, financial constraints, or apprehension about leaving the safety of Japan (Nagahashi, 2007). As study abroad is becoming a larger part of university educational programs, further research into what affective factors help facilitate study-abroad experiences is needed.

\section{Relationships Between Factors}

Studying abroad has been found to aid in many facets of the language learning process, not only in language acquisition but also aiding learners in psychological factors of language learning. Researchers have observed changes related to proficiency gains during and after study-abroad programs. Tanaka and Ellis (2003) observed changes in proficiency as well as significant increases in self-efficacy. Amuzie and Winke (2009) found that self-efficacy increased most among study-abroad groups who studied longer than a 6-month period. Other studies have also shown similar findings related to affective factors. Cubillos and llvento (2012) found participation in study abroad had a significant impact on learners' self-efficacy in reading, writing, speaking, and listening. Similar findings can be seen in relation to foreign language anxiety and studying abroad. Thompson and Lee (2013) found that time spent abroad can affect English language class anxiety, confidence communicating with native speakers, and diminish fear of ambiguity in English. Matsuda and Gobel (2003) observed that length of study abroad could be a factor related to speaking confidence, which then could affect performance in foreign language classes. This was further supported by Saito and lida (2015). Relating to these two affective factors, Maclntyre, Noels, and Clement (1997) assert that anxiety results from low self-efficacy. Furthermore, Dornyei (1994) places language use anxiety and selfefficacy under determiners of self-confidence.

\section{Foreign Language Anxiety}

The role that foreign language anxiety plays in second language acquisition has been well researched within the field for many years. Horowitz et al. (1986) described foreign language anxiety as being its own unique type of anxiety, defining it as a "subjective feeling of tension, apprehension, nervousness, and worry" (p. 125) that may be particularly disruptive in the language classroom. These affective factors, along with cognitive factors, affect learning contexts in both formal and informal situations, inside and outside the classroom (Gardner \& Maclntyre, 1992). The effect of anxiety on speaking and listening interactions in the classroom has been researched (Horowitz et al., 1986; Maclntyre \& Garden, 1991), but anxiety has also been shown to affect writing and reading domains as well (Hilleson, 1996; Cheng, Horwitz, \& Schaller, 1999).

Foreign language anxiety, along with other affective factors, can affect willingness and frequency of engagement in conversation, especially in classrooms (Yashima, 2002). This anxiety could lead to withdrawal from interactions with speakers in a study-abroad context. High anxiety or threatening environments coupled with low achievement in a language learning context may lead to disinterest and withdrawal from language learning, or similar results (Gardner, Moorcroft, \& MacIntyre, 1987; Nagahashi, 2007).

For learners specifically in Japan, English can be viewed as stressful due to communicating in English with people who do not share the same cultural values (Yashima, Zenuk-Nishide, \& Shimizu, 2004). This underlying factor can lead to potential barriers in communication amongst people from different cultures, but it could be an avenue that allows for greater communication among students who come from other Asian countries with similar language learning backgrounds.

\section{Self-Efficacy}

Along with anxiety, self-efficacy, "the belief in one's capabilities to organize and execute a course of action required to produce given attainments" (Bandura, 1997, p. 3), can be a predictor of success in language learning, along with the use of learning strategies and other affective factors. Students holding high self-efficacy generally were shown to be more proficient (Hseih \& Kang, 2010; Hseih \& Schallert, 2008) and are likely to engage more actively in the target language, reflected in the language classroom as participating in activities, actively answering questions, or participating in group work (Maclntyre, Clement, Dornyei, \& Noels, 1998; Schunk, 1990); those with low self-efficacy are more likely to avoid situations involving language use (Schunk, 1990) and have been connected with a reluctance to continue studies or withdraw from participation. 
Positive self-efficacy has been found to be related to achievement in academic tasks inside and outside of language learning (Huang \& Chang, 1998; Jones, 2008; Lane \& Lane, 2001; Onoda 2013; Schunk, 1981). This has been partially corroborated in previous research in which self-efficacy has been shown to at least be partly correlated to performance on academic achievement tests, specifically in relation to the passive reading and listening skills (Marx \& Klassen, 2020).

Self-efficacy can differ depending on language domains (speaking, listening, reading, and writing) (Bong \& Skaalvik, 2003) and may be obfuscated by cultural factors (Macintyre et al., 1998), such as a culture that prefers teacher-led classrooms to studentcentered teaching.

\section{Methodology \\ Participants}

The participants of this study consisted of 40 university students at a small private university in Japan. All participants were informed of the study and asked to sign bilingual consent forms in English and Japanese that had been approved by the institution. Participants had average predeparture IELTS scores of 5.0.

In this program, participants were enrolled in an intensive English program for three academic quarters prior to study abroad. The study-abroad period begins in the fourth academic quarter and extends into the beginning of the students' second year. This program took place in a number of universities around the world, including institutions in Australia, New Zealand, Ireland, the United States of America, Canada, the Czech Republic, the Netherlands, the Philippines, Malaysia, and Taiwan. Study abroad duration was 4 to 5 months, with students taking a variety of courses depending on their English abilities, determined by their IELTS scores. Primarily, these participants studied English language courses, though some qualified for academic content classes with local students at the host institution.

\section{Measurement Tools}

Two quantitative questionnaires were used in this study to collect data on foreign language anxiety in a classroom environment and to observe perceptions of English self-efficacy. In regards to self-efficacy, the Questionnaire of English Self-Efficacy (QESE) was used (Wang, 2004). This 32-item 7-point Likert scale questionnaire (Wang, 2004) was validated through a series of studies in Asian contexts (Kim, Wang, Ahn, \&
Bonh, 2015; Ngoc Truong, \& Wang, 2019; Wang, Kim, Bai, \& Hu, 2014; Wang, Schwab, Fenn, \& Chang, 2013). A modified Japanese version of the QESE, translated by the researchers (Marx \& Klassen, 2020) was used (Appendix A). The main changes made in this translation were related to wording and familiarity of the tasks. One question was deleted as the researchers judged it to be contextually unfamiliar to participants. Regardless of the changes, the reliability of the Japanese translation in its previous use was very high $(\alpha=.96)$.

Anxiety was measured using the Foreign Language Classroom Anxiety Scale (FLCAS) created by Horwitz, Horwitz, and Cope (1986). This scale has been used extensively in foreign language research over the past 30 years (Horwitz, 2001). The version used in this study was a Japanese translation created by Yashima et al. (2009; see Appendix B). This questionnaire was used in its entirety, consisting of 33 items that utilized a 5-point Likert scale that relates to levels of self-reported anxiety with 1 corresponding to low anxiety and 5 corresponding to high anxiety. Some questions were worded in a way that 5 corresponds to a low level of anxiety; questions $2,5,8,11,14,18,22,28$, and 32 have been reverse coded. The original and the translation have been found to be a popular method of measuring quantitative foreign language anxiety (Kawashima, 2009; Teimouri, Goetze, \& Plonsky, 2019).

The questionnaires were administered twice: (a) the pretest during the third term of the participants first year of study (Weeks 10-13) and (b) the posttest after participants returned from the study-abroad program midway through their 2 nd year (within five weeks after their return).

\section{Results}

Results show some variance in the data in the pre- and posttests in this study. The descriptive statistics found in Table 1 show the FLCAS pretest had a higher level of anxiety $(M=2.76, S D=0.53)$ than on the posttest $(M=2.54, S D=0.50)$. The Japanese translation of the QESE used in this study showed similar findings, with a lower value on the pretest $(M=4.30, S D=0.66)$ than in the posttest $(M=4.95, S D=0.72)$. The measurement tools were both found to be highly reliable with the FLCAS having a pretest reliability of $\alpha=.91$ and a posttest reliability of $\alpha=.90$. In addition, the JQESE was also found to be highly reliable in both the pre- and posttests: $\alpha=.90$ and $\alpha=.96$ respectively. 
Table 1. Descriptive Statistics for the Foreign Language Anxiety and Self-Efficacy Questionnaire Totals: FLCAS and JQESE Measurements

\begin{tabular}{lcccc}
\hline \multicolumn{1}{c}{ Test } & $M$ & $\mathrm{~N}$ & SD & SEM \\
\hline FLCAS Pretest & 2.76 & 40 & 0.53 & 0.08 \\
FLCAS Posttest & 2.54 & 40 & 0.50 & 0.08 \\
QESE Pretest & 4.30 & 40 & 0.66 & 0.10 \\
QESE Posttest & 4.95 & 40 & 0.72 & 0.11 \\
\hline
\end{tabular}

Note. FLCAS = Foreign Language Classroom Anxiety Scale. JQESE = the Japanese Questionnaire of English Self-Efficacy

Paired samples $t$ tests were performed between the total scores of FLCAS in the preand posttest in addition to the JQESE also in the pre- and posttest. The data suggests that there was a strong significant difference between the results in both tests before and after studying abroad. There was a significant negative difference in the mean scores of the preand post-FLCAS results $(t(39)=3.65, p=.01$, two-tailed) as well as a significant positive change in self-efficacy shown in the pre- and post-JQESE $(t(39)=-6.80, p<.00$, two-tailed).

Table 2 and 3 show the correlation between the pretest of the JQESE in relation to the FLCAS pretest. Results indicated a significant negative correlation between the results of the FLCAS and the JQESE on the pretest $(r=-.56, p<.001)$. This was similar in the posttest between the two measurements, which also had a significant negative correlation $(r=-.50, p=.01)$. The results from these analyses indicate that there is a possible connection between foreign language anxiety and English self-efficacy. This data shows that when anxiety is higher, self-efficacy is lower and vice versa.

Table 2. Correlations Between Foreign Language Anxiety and SelfEfficacy Questionnaires: FLCAS and JQESE Pretests $(N=40)$

\begin{tabular}{lllc}
\hline & Spearman's rho & FLCAS & JQESE \\
\hline FLCAS Pretest & Correlation coefficient & 1.000 & $-.549 * *$ \\
& Sig. (2-tailed) &. & .000 \\
\multirow{2}{*}{ JQESE Pretest } & Correlation coefficient & $-.549 * *$ & 1.000 \\
& Sig. (2-tailed) & .000 &. \\
\hline
\end{tabular}

Table 3. Correlations Between Foreign Language Classroom Anxiety and Self-Efficacy Questionnaires: FLCAS and JQESE Posttests $(N=40)$

\begin{tabular}{llll}
\hline & Spearman's rho & FLCAS & QESE \\
\hline \multirow{2}{*}{ FLCAS Posttest } & Correlation coefficient & 1.000 & $-.500 * *$ \\
& Sig. (2-tailed) &. & .001 \\
\multirow{2}{*}{ JQESE Posttest } & Correlation coefficient & $-.500 * *$ & 1.000 \\
& Sig. (2-tailed) & .001 &. \\
\hline
\end{tabular}

In addition, analyses on the language domains of the JQESE in terms of correlations to the FLCAS were performed. These correlations observed possible statistical relationships between the tests. The FLCAS pretest (Table 4) was correlated to all factors of the JQESE pretest language domains. This can also be seen in the FLCAS posttest data compared to the JQESE posttest (Table 5).

Table 4. Correlations Between Foreign Language Classroom Anxiety and Listening, Reading, Writing, and Speaking Self-Efficacy: FLCAS and JQESE Language Domains Pretest $(N=40)$

\begin{tabular}{lcccc}
\hline \multicolumn{1}{c}{ Spearman's rho } & \multicolumn{4}{c}{ Self-efficacy measure } \\
\cline { 2 - 5 } FLCAS pretest mean score & Listening & Reading & Writing & Speaking \\
\hline Correlation coefficient & $-.50 * *$ & $-.49 * *$ & $-.40 *$ & $-.46 * *$ \\
Sig. (2-tailed) & .001 & .002 & .011 & .003 \\
\hline
\end{tabular}

Note. FLCAS = Foreign Language Classroom Anxiety Scale. JQESE = the Japanese Questionnaire of English Self-Efficacy.

* Correlation is significant at the .05 level (2-tailed).

** Correlation is significant at the .01 level (2-tailed). 
Table 5. Correlations Between Foreign Language Classroom Anxiety and Listening, Reading, Writing, and Speaking Self-Efficacy: FLCAS and JQESE Language Domains Posttest

\begin{tabular}{lllll}
\hline \multirow{2}{*}{ Spearman's rho } & \multicolumn{4}{c}{ JQESE posttest } \\
\cline { 2 - 5 } FLCAS posttest mean score & Listening & Reading & Writing & Speaking \\
\hline Correlation coefficient & $-.44 * *$ & $-.62 * *$ & $-.37 *$ & $-.47 * *$ \\
Sig. (2-tailed) & .005 & .000 & .019 & .002 \\
\hline
\end{tabular}

Note. FLCAS = Foreign Language Classroom Anxiety Scale.

* Correlation is significant at the 05 level (2-tailed).

** Correlation is significant at the .01 level (2-tailed).

Table 6 shows the individual questions that had significant changes on the FLCAS (see Appendix B and C) between the pretest and posttest. Though the mean total significantly changed between these two survey administrations, results on only nine of the 33 questions showed a significant change, all being significant decreases in anxiety. Results for the JQESE showed positive significant changes indicating increased self-efficacy for all questions but two. For this, it is important to look at which two questions did not significantly change over time for self-efficacy: Question $25(\mathrm{t}(39)=.37, p=.72)$ and Question $31(\mathrm{t}(39)=-1.96, p=.06)$ (Appendix A).

Table 6. Paired Samples T Test Examining Significant Changes on Individual Items of the FLCAS: Pre- and Posttest Significance

\begin{tabular}{lccccccc}
\hline \multicolumn{1}{c}{ Question } & $M$ & $S D$ & SEM & $95 \% \mathrm{Cl}$ & $t$ & $d f$ & Sig. (2-tailed) \\
\hline 1 & .73 & 1.11 & .18 & {$[.370,1.080]$} & 4.13 & 39 & .000 \\
4 & .73 & 1.18 & .19 & {$[.349,1.101]$} & 3.90 & 39 & .000 \\
5 & .48 & 1.20 & .19 & {$[.092, .858]$} & 2.51 & 39 & .016 \\
7 & .53 & 1.20 & .19 & {$[.142, .908]$} & 2.77 & 39 & .009 \\
10 & .63 & 1.55 & .25 & {$[.130,1.120]$} & 2.56 & 39 & .015 \\
11 & .43 & 1.06 & .17 & {$[.086, .764]$} & 2.54 & 39 & .015 \\
14 & .53 & 1.30 & .21 & {$[.109, .941]$} & 2.553 & 39 & .015 \\
17 & .43 & 1.04 & .16 & {$[.094, .756]$} & 2.597 & 39 & .013 \\
32 & .68 & 1.05 & .17 & {$[.340,1.010]$} & 4.076 & 39 & .000 \\
\hline
\end{tabular}

Note. $\mathrm{Cl}=$ confidence interval.

\section{Discussion}

Overall foreign language classroom anxiety decreased after studying abroad. In addition to this, nine items from the FLCAS were found to have a significant negative change between the two measurement times. Of the questions found to have a significant variance, Questions 5, 11,14, and 32 were reverse coded, so a higher number indicated a higher level of perceived anxiety.

FLCAS questions that had significant changes are as follows:

1. I never feel quite sure of myself when I am speaking in my foreign language class.

4. It frightens me when I don't understand what the teacher is saying in the foreign language.

5. It wouldn't bother me at all to take more foreign language classes.

7. I keep thinking that the other students are better at languages than I am.

10. I worry about the consequences of failing my foreign language class.

11. I don't understand why some people get so upset over foreign language classes.

14. I would not be nervous speaking the foreign language with native speakers.

17. I often feel like not going to my language class.

32. I would probably feel comfortable around native speakers of the foreign language.

All of the items from the FLCAS listed above had a significant negative decrease between pre- and postadministration. This ultimately led to a significant negative change on overall anxiety of the FLCAS, meaning that anxiety was lower for these responses.

Participants seemed to have a more positive perception of language classes, as seen in Questions 5 and 17. The participants also seemed to be more comfortable with their teachers and other native English speakers as seen in Questions 4, 14, and 32. Questions 1 and 7 are related to the participants' self-perception of language ability, which shows that study abroad could be a catalyst to lowering anxiety. These results support the findings from previous research, in which learners had a greater willingness to engage in their foreign language classes (Gardner, Moorcroft, \& Maclntyre, 1987; Nagahashi, 2007), were less anxious and more willing to communicate in the target language (Yashima, 2002), and, for learners from Japan, indicated that speaking with native speakers is not such an anxiety ridden experience (Yashima, Zenuk-Nishide, \& Shimizu, 2004). 
Self-efficacy questions that did not change significantly were the following:

25. Can you find out the meanings of new words using a word dictionary?

31. Can you understand new reading materials selected by your instructor?

The nonsignificant findings are related to questions about reading on the JQESE. However, the other 29 questions all had significantly positive change between the tests. The difference could be due to self-efficacy being different among language domains (speaking, listening, reading, and writing) (Bong \& Skaalvik, 2003). Some possible explanations for these nonsignificant findings could be tied to the possibility of continuing difficulty with reading materials in class or even in what ways reading instruction took place (McLean \& Poulshock, 2019).

Looking at the correlations, some possible relationships can be observed. The FLCAS was found to have a significant negative correlation to the JQESE on both the pretest and posttest, suggesting a negative relationship between these affective factors. When anxiety is high, learners' efficacy is low and vice versa. Though the FLCAS is generally considered to be more related to speaking anxiety within the language classroom (Aida, 1994), it was found to be correlated to all language domains of the JQESE. This relationship suggests that language anxiety measured by the FLCAS could play a role in self-efficacy in all aspects of language learning.

\section{Implications and Limitations}

\section{Implications}

Anxiety across the board decreased for the participants in this study. The nine questions featured above in the FCLAS survey showed a decrease in anxiety in participating in a FL classroom, understanding ambivalence in English, comparing themselves to other classmates, interactions with native speakers, classroom participation, and potential for further study. As reported in a study of similar learners (Klassen, 2018), students felt less apprehension speaking English after having interacted with EFL speakers from other countries and had a favorable experience in classrooms abroad, which offered more opportunities for interaction and language feedback.

One point that could be made from these results is that for gains in self-efficacy and reduction in anxiety, study abroad needs to be an extension of language study in a language learning course. Increasing students' exposure to the target language in Japan should be paramount in importance for developing positive affect factors. Students will often experience a shock in their foreign language communicative activities when first studying abroad. Adapting a classroom style akin to those they will find at their studyabroad destination may help to bridge this gap.

\section{Limitations}

Some limitations of this study are primarily related to the measurements used. Some possible limitations relating to the FLCAS are concerned with interpretations of foreign language classroom anxiety and its factor loading as proposed by Aida (1994). Aida (1994) proposed an alternative version of the FLCAS with only items that were found to be correlated in groups. It might be beneficial to replicate the study with a modified FLCAS that relates to the main components of foreign language classroom anxiety.

In addition, the FLCAS uses the term "native speaker," which privileges interactions with speakers from the inner circle of English speaking countries (Kachru, 1986). However, many of the students interacted with other nonnative speakers of English during their study-abroad destinations. Study-abroad students are more likely to interact with conationals and nationals from other EFL backgrounds instead of with local speakers (Coleman, 2013). Therefore, local speakers of English would be a more meaningful term in a study-abroad context than "native speaker."

There may also be some limitations associated with the JQESE. Primarily, the QESE is not specifically a test of academic English self-efficacy. However, the language courses students take during their first year of university are all related to academic English, especially dealing with academic achievement tests. In addition, the JQESE used in this study had been partially modified for the Japanese language context. Although the JQESE used in this study had a high reliability score, the original unmodified English version of the QESE could give more support to the findings.

Finally, study-abroad exposure was different between individuals and groups of students in terms of study-abroad destination and time abroad. All students studied four to five months during their time abroad, so there could be a possible one-month gap between the shortest time abroad and the longest. In addition to this, the location of study abroad and the amount of class time also varies between the learners. This inconsistency could also be a limitation. However, for practical purposes, it lets the students choose their study abroad more confidently.

\section{Conclusion}

The present study looked at changes in self-efficacy and foreign language anxiety before and after participants studied abroad. The study found possible positive effects 
of studying abroad on both levels of self-efficacy and foreign language anxiety. Selfefficacy significantly increased while foreign language anxiety significantly decreased. In addition, correlations were seen in the pretest between self-efficacy and language anxiety that were maintained in the posttest, which showed a negative correlation between these factors, hinting at a potential link that needs to be further explored.

Anxiety specifically related to attitudes toward English classes, communicating with perceived native speakers, and communication with language teachers found significant improvements. Although all levels of self-efficacy improved, the only two questions that had no significant improvements were related to reading. However, self-efficacy improved in other language domains. Study abroad can be seen in this study to be a factor in improving English language anxiety and English self-efficacy.

\section{Bio Data}

Marshall Klassen is an associate professor at Kanazawa Seiryo University. He is currently interested in studying discourse and study abroad. <Marshall.Klassen@gmail.com>

Nicholas Marx is currently a Shokutaku English instructor at Ritsumeikan University. He is interested in affective factors and task-based language teaching. $<$ Nicholas.D.Marx@gmail.com>

\section{References}

Aida, Y. (1994). Examination of Horwitz, Horwitz, and Cope's construct of foreign language anxiety: The case of students of Japanese. The Modern Language Journal, 78(2), 155-168. https:// doi.org/10.1111/j.1540-4781.1994.tb02026.x

Amuzie, G. L., \& Winke, P. (2009). Changes in language learning beliefs as a result of study abroad. System, 37(3), 366-379. https://doi.org/10.1016/j.system.2009.02.011

Bandura, A. (1982). Self-efficacy mechanism in human agency. American Psychologist, 37(2), 122 147. https://doi.org/10.1037/0003-066X.37.2.122

Bandura, A. (1997). Self-efficacy: The exercise of control. New York, NY: W. H. Freeman.

Bong, M., \& Skaalvik, E. M. (2003). Academic self-concept and self-efficacy: How different are they really? Educational Psychology Review, 15(1), 1-40. https://doi.org/10.1023/A:1021302408382

Cheng, Y., Horwitz, E. K., \& Schallert, D. L. (1999). Language anxiety: Differentiating writing and speaking components. Language Learning, 49, 417-446. https://doi.org/10.1111/00238333.00095
Coleman, J. A. (2013). Researching whole people and whole lives. In C. Kinginger (Ed.), Social and cultural dimensions of language learning in study abroad (pp. 17-44). Amsterdam, The Netherlands: John Benjamins.

Cubillos, J. H., \& Ilvento, T. (2012). The impact of study abroad on students' self-efficacy perceptions. Foreign Language Annals, 45, 494-511. https://doi.org/10.1111/j.19449720.2013.12002.x

Dornyei, Z. (1994). Motivation and motivating in the foreign language classroom. The Modern Language Journal, 78(3), 273-284. https://doi.org/10.2307/330107

English teachers to study abroad. (2013, December 7). The Japan Times. Retrieved from https:// www.japantimes.co.jp/

Gardner, R. C., \& MacIntyre, P. D. (1992). A student's contributions to second language learning. Part I: Cognitive variables. Language Teaching, 25(4), 211-220. https://doi.org/10.1017/ s026144480000700x

Gardner, R. C., Moorcroft, R., \& Maclntyre, P. D. (1987). The role of anxiety in second language performance of language dropouts. (Research Bulletin No. 657). London, ON, Canada: The University of Western Ontario, Department of Psychology.

Hilleson, M. (1996). "I want to talk with them, but I don't want them to hear": An introspective study of second language anxiety in an English-medium school. In K. Bailey \& D. Nunan (Eds.), Voices from the language classroom: Qualitative research in second language acquisition (pp. 248-275). New York, NY: Cambridge University Press.

Hsieh, P. P. H., \& Kang, H. S. (2010). Attribution and self-efficacy and their interrelationship in the Korean EFL context. Language Learning, 60(3), 606-627. https://doi.org/10.1111/j.14679922.2010.00570.x

Hsieh, P. H. P., \& Schallert, D. L. (2008). Implications from self-efficacy and attribution theories for an understanding of undergraduates' motivation in a foreign language course. Contemporary Educational Psychology, 33(4), 513-532. https://doi.org/10.1016/j.cedpsych.2008.01.003

Horwitz, E. K. (2001). Language anxiety and achievement. Annual Review of Applied Linguistics, 21, 112-126. https://doi.org/10.1017/s0267190501000071

Horwitz, E. K., Horwitz, M. B. \& Cope, J. (1986). Foreign Language Classroom Anxiety. The Modern Language Journal, 70(2), 125-132. https://doi.org/10.1111/j.1540-4781.1986.tb05256.x

Huang, S. C., \& Chang, S. F. (1998). Self-efficacy in learners of English as a second language: Four examples. Journal of Intensive English Studies, 12, 23-40. Retrieved from https://eric. ed.gov/?id=EJ583955

Jones, E. (2008). Predicting performance in first-semester college basic writers: Revisiting the role of self-beliefs. Contemporary Educational Psychology, 33(2), 209-238.https://doi.org/10.1016/j. cedpsych.2006.11.001 
Kachru, B. B. (1986). The power and politics of English. World Englishes, 5(2-3), 121-140. https:// doi.org/10.1111/j.1467-971X.1986.tb00720.x

Kawashima, T. (2009). FL anxiety studies of Japanese EFL learners: A critical review. In A. M. Stoke (Ed.), JALT2008 Conference Proceedings. Tokyo: JALT. Retrieved from https://jalt-publications. org/recentpdf/proceedings/2008/E120.pdf

Kim, D. H., Wang, C., Ahn, H. S., \& Bong, M. (2015). English language learners' self-efficacy profiles and relationship with self-regulated learning strategies. Learning and Individual Differences, 38 136-142. https://doi.org/10.1016/j.lindif.2015.01.016

Klassen, M. (2018). An inquiry into study abroad: Considerations for Japanese students studying abroad. Kanazawa Seiryo University Bulletin of the Humanities, 3(2). 43-52. Retrieved from http:// www.seiryo-u.ac.jp/u/education/gakkai/humanities_ronsyu_pdf/No3_2/03_klassen.pdf

Lane, J., \& Lane, A. (2001). Self-efficacy and academic performance. Social Behavior and Personality: An International Journal, 29(7), 687-693. https://doi.org/10.2224/sbp.2001.29.7.687

MacIntyre, P. D., Clément, R., Dörnyei, Z., \& Noels, K. A. (1998). Conceptualizing willingness to communicate in a L2: A situational model of $\mathrm{L} 2$ confidence and affiliation. The Modern Language Journal, 82(4), 545-562. https://doi.org/10.1111/j.1540-4781.1998.tb05543.x

MacIntyre, P. D., \& Gardner, R. C. (1991). Language anxiety: Its relationship to other anxieties and to processing in native and second languages. Language Learning, 41, 513-534. https://doi. org/10.1111/j.1467-1770.1991.tb00691.x

MacIntyre, P. D., Noels, K. A., \& Clément, R. (1997). Biases in self-ratings of second language proficiency: The role of language anxiety. Language Learning, 47(2), 265-287. https://doi. org/10.1111/0023-8333.81997008

Marx, N., \& Klassen, M. (2020). Self-efficacy and IELTS: A case of EAP learners in Japan. NEAR Conference Proceedings 2019. Manuscript submitted for publication.

Matsuda, S. and Gobel, P. (2004). Anxiety and predictors of performance in the foreign language classroom. System, 32(1), 21-36. https://doi.org/10.1016/j.system.2003.08.002

McLean, S., \& Poulshock, J. (2018). Increasing reading self-efficacy and reading amount in EFL learners with word-targets. Reading in a Foreign Language, 30(1), 76-91. https://eric. ed.gov/?id=EJ1176293

MEXT. (2014). Tobitate! Ryugaku JAPAN. Retrieved from http://www.mext.go.jp/a_menu/kokusai/ tobitate/

Nagahashi, T. (2007). A cross-sectional study of foreign language learning anxiety among freshmen at Akita University. Bulletin of the Center for Educational Research and Practice, Akita University, 29, 93-102. Retrieved from https://air.repo.nii.ac.jp/?action=pages_view_main\&active_ action=repository_view_main_item_detail\&item_id=890\&item_no=1\&page_id=13\&block_id=21
Ngoc Truong, T., \& Wang, C. (2019). Understanding Vietnamese college students' self-efficacy beliefs in learning English as a foreign language. System, 84, 123-132. https://doi.org/10.1016/j. system.2019.06.007

Onoda, S. (2013). Exploration of the relationships among self-efficacy, self-regulation strategy use, and English vocabulary skills. Studies in Linguistics and Language Teaching, 24, 107-125. https:// sisaljournal.org/archives/dec14/onoda/

Saito, T., \& lida, T. (2015). Speaking anxiety and the effects of previous overseas experience in an English intensive program before study abroad. Papers in Language, Literature, and Culture of the Graduate School of Doshisha Women's College of Liberal Arts, 15, 1-24. Retrieved from https://dwcla.repo.nii.ac.jp/index.php?action=pages_view_main\&active_action=repository_ action_common_download\&item_id=892\&item_no=1\&attribute_id=22\&file_no=1\&page $\mathrm{id}=13$ \&block_id=21

Schunk, D. H. (1981). Modeling and attributional effects on children's achievement: A self-efficacy analysis. Journal of Educational Psychology, 73(1), 93-105. https://doi.org/10.1037/00220663.73.1.93

Schunk, D. H. (1990). Goal setting and self-efficacy during self-regulated learning. Educational Psychologist, 25(1), 71-86. https://doi.org/10.1207/s15326985ep2501_6

Tanaka, K., \& Ellis, R. (2003). Study-abroad, language proficiency, and learner beliefs about language learning. JALT Journal, 25(1), 63-85. https://doi.org/10.37546/JALTJJ25.1-3

Teimouri, Y., Goetze, J., \& Plonsky, L. (2019). Second language anxiety and achievement. Studies in Second Language Acquisition, 41(2), 363-387. https://doi.org/10.1017/S0272263118000311

Thompson, A. S., \& Lee, J. (2013). Anxiety and EFL: does multilingualism matter? International Journal of Bilingual Education and Bilingualism, 16(6), 730-749. https://doi.org/10.1080/1367005 0.2012 .713322

Wang, C. (2004). Self-regulated learning strategies and self-efficacy beliefs of children learning English as a second language (Doctoral dissertation, Ohio State University). Retrieved from http://rave.ohiolink.edu/etdc/view?acc_num=osu1091546670

Wang, C. \& Kim, D. H. \& Bai, R, \& Hu, J. (2014). Psychometric properties of a self-efficacy scale for English language learners in China. System, 44. 24-33. https://doi.org/10.1016/j. system.2014.01.015

Wang, C., Schwab, G., Fenn, P., \& Chang, M. (2013). Self-efficacy and self-regulated learning strategies for English language learners: Comparison between Chinese and German college students. Journal of Educational and Developmental Psychology, 3(1), 173-191. https://doi. org/10.5539/jedp.v3n1p173

Yashima, T. (2002). Willingness to communicate in a second language: The Japanese EFL context. The Modern Language Journal, 86(1), 54-66. https://doi.org/10.1111/1540-4781.00136 
Yashima, T., Shizuka, T., Yamane, S., Noels, K. A., Takeuchi, O., \& Yoshizawa, K. (2009). Motivation and gender in the Japanese EFL classroom. Kansai University Journal of Foreign Language Education and Research, 17, 41-64. https://doi.org/10.1016/j.system.2005.11.002

Yashima, T., Zenuk-Nishide, L., \& Shimizu, K. (2004). The influence of attitudes and affect on willingness to communicate and second language communication. Language Learning, 54(1), 119-152. hrrps://doi.org/10.1111/j.1467-9922.2004.00250.x

Young, D. J. (1999). Affect in foreign language and second language learning: A practical guide to creating a low-anxiety classroom atmosphere. Boston, MA: McGraw-Hill.

\section{Appendix A}

Japanese Questionnaire of English Self-Efficacy (Marx \& Klassen, 2020)

これらの質問に応じて以下のスケールを使用してください。あなたの能力を正確に表す数字を選 んでください。(English translations were not included in the original questionnaire)

英語で語つた物語を理解することができますか。

(Can you understand stories told in English?)

1234567

英語のテキストを使用する宿題を一人でできるか。

(Can you do homework/home assignments alone when they include 12234567 reading English texts?)

英語のテレビ番組・プログラムを理解することができますか。

(Can you understand English-language TV programs?)

自分の大学について英語で説明することができますか。

(Can you describe your university to other people in English?)

インターネットのサイトや揭示板に英語で投稿ができますか。(Facebook,

twitter, blogs, etc.)?

(Can you compose messages in English on the Internet (face book,

twitter, blogs, etc.)?)

家から大学までの道案内は英語でできますか。

(Can you describe the way to the university from the place where you 1234567 live in English?)
英語のショートメール(SNSメッセージ)を書くことができますか。 (Line,

Facebook messenger, twitter DM)?

(Can you write a text message in English? Such as Line, Facebook messenger, twitter DM?)

英語で物語を語ることができますか。

(Can you tell a story in English?)

英語を公用語としている国のラジオ番組を理解することができますか。

(Can you understand radio programs in English-speaking countries?)

英語でメモを書き残すことができますか。

(Can you leave a note for another student in English?)

英語のテキストの分からない言葉の意味を推測することができますか。

(Can you guess the meaning of unknown words when you are

reading an English text?)

あなたは今学んだ英単語から新しい文章を作ることができますか?

(Can you form new sentences from words you have just learnt?)

英語でe-メールを書くことができますか

(Can you write emails in English?)

学生生活についての英語会話(録音したもの)を理解することができますか。

(Can you understand English dialogues (audio recordings) about

everyday school matters?

インターネットの英語のメッセージやニュースを理解することができますか。

(Can you understand messages or news items in English on the internet?)

先生に英語で質問することができますか。

(Can you ask your teacher questions in English?)

234567

1234567

1234567

1234567

英語のイディオム(熟語)を使って文章を作ることができますか。

(Can you produce English sentences with idiomatic phrases?)

先生を英語で誰かに紹介することができますか。

(Can you introduce your teacher (to someone else) in English?) $\begin{array}{lllllll}1 & 2 & 3 & 4 & 5 & 6 & 7\end{array}$

1234567

1234567

1234567

1234567

1234567

1234567

1234567 
クラスメートと一般的な話題を英語で話し合うすることができますか。

(Can you discuss subjects of general interest with your fellow students in English?)

短い英語の物語を読むことができますか?

(Can you read short English narratives?)

字幕つけなくても英語の映画を理解することができますか。

(Can you understand English films without subtitles?)

先生の英語の質問は英語で答えることができますか。

(Can you answer your teacher's questions in English?)

英語の歌を理解することができますか。

(Can you understand English songs?)

英字新聞を理解することができますか。

(Can you read English-language newspapers?)

単語辞書を使って新しい単語の意味を調べることはできますか?

(Can you find out the meanings of new words using a word

\section{dictionary?)}

英語での電話番号を理解することができますか。

(Can you understand telephone numbers spoken in English?)

英語で日記を書くことができますか。

(Can you write diary entries in English?)

日本の文化に関する英語の記事を理解できますか?

(Can you understand English articles on Japanese culture?)

自己紹介を英語でできますか。

(Can you introduce yourself in English?)

知っている有名人についての 2ページのレポートを英語で書くことができます

か。(Can you write an essay in about two pages about your lecturer in

English?)

指導者によって選ばれた新しい英語のリーデイング教材を理解することがで

きますか。

(Can you understand new reading materials selected by your instructor?)
1234567

1234567

1234567

1234567

1234567

1234567

1234567

1234567

1234567

1234567

1234567

1234567

1234567

Appendix B

Japanese Translated Foreign Language Classroom Anxiety Scales (Yashima et al., 2009)

これらの質問に応じて以下のスケールを使用してください。あなたの能力を正確に表す数字を選 んでください。

外国語の授業で話すとき自信がもてない。

外国語の授業で間違うことは気にならない。

12345

外国語の授業で当てられると思うと体が震える。

123345

外国語の授業で先生の言っていることが理解できないととても不安だ。

122345

もっと外国語の授業があってもよいと思っている。

外国語の時間授業と関係ないことを考えていることがよくある。

12345

他の生徒の方が自分よりよくできると思っている。

1223445

外国語の授業中のテストではだいたい落ち着いている。

12345

外国語の授業で準備なしに話さないといけない時、パニックになる。

122345

$\begin{array}{lllll}1 & 2 & 3 & 4 & 5\end{array}$

外国語の単位を落としたときの影響が心配だ。

123345

外国語の授業で動摇する人の気持ちがわからない。

123345

外国語の授業では、緊張のあまり、知ってたことも忘れてしまうときがある。

123345

外国語の授業で自分からすすんで答えるのは恥ずかしい。

12345

外国語をネーティブスピーカーと話すとき緊張しない。

12345

先生が何を訂正しているのか理解できないとき動摇する。

12345

外国語の授業の予習を十分にしていても心配になる。

12345

よく外国語の授業を休みたくなる。

外国語の授業で話すのに自信がある。

122345

先生が自分の間違いをいちいち直しそうなので心配だ。

12345

外国語のクラスで当たりそうになると胸がどきどきする。

123345

外国語のテスト勉強をすればするほど、混乱する。

122345

外国語の授業の予習をよくしないといけないというプレッシャーは感じない。

123345

常に他の学生の方が外国語で話すのが上手だと感じている。

12345

12345 
Klassen \& Marx: Anxiety, Self-Efficacy, and the Role of Study Abroad

\begin{tabular}{|c|c|}
\hline 他の学生の前で外国語を話すとき自意識がとても高くなる。 & 123345 \\
\hline 外国語のクラスは進むのが速いのでついていけるかどうか心配である。 & 12345 \\
\hline 他の科目よりも外国語のクラスの方か緊張する。 & 12345 \\
\hline 外国語のクラスで話すとき緊張したり混乱したりする。 & 12345 \\
\hline 外国語のクラスに向かうとき自信をもてるしリラックスしている。 & 12345 \\
\hline 先生の言うことがすべて理解できないと不安になる。 & 12345 \\
\hline $\begin{array}{l}\text { 外国語を話すためにあまりに多くの文法規則を勉強しないといけないので圧倒さ } \\
\text { れる。 }\end{array}$ & 12345 \\
\hline 私が外国語を話すと他の学生が笑うのではないかと思う。 & 12345 \\
\hline ネーティブスピーカーに会うときおそらくリラックスしていられると思う。 & 12345 \\
\hline 先生が、前もって準備していなかった質問をすると緊張する。 & 12345 \\
\hline
\end{tabular}

Appendix C

Foreign Language Classroom Anxiety Scale (Horwitz et al., 1986)

1. I never feel quite sure of myself when I am speaking in my foreign language class.

2. I don't worry about making mistakes in language class.

3. I tremble when I know that I'm going to be called on in language class.

4. It frightens me when I don't understand what the teacher is saying in the foreign language.

5. It wouldn't bother me at all to take more foreign language classes.

6. During language class, I find myself thinking about things that have nothing to do with the course.

7. I keep thinking that the other students are better at languages than $\mathrm{I}$ am.

8. I am usually at ease during tests in my language class.

9. I start to panic when I have to speak without preparation in language class.

10. I worry about the consequences of failing my foreign language class.

11. I don't understand why some people get so upset over foreign language classes.

12. In language class, I can get so nervous I forget things I know.

13. It embarrasses me to volunteer answers in my language class.

14. I would not be nervous speaking the foreign language with native speakers.
15. I get upset when I don't understand what the teacher is correcting.

16. Even if I am well prepared for language class, I feel anxious about it

17. I often feel like not going to my language class.

18. I feel confident when I speak in foreign language class.

19. I am afraid that my language teacher is ready to correct every mistake I make.

20. I can feel my heart pounding when I'm going to be called on in language class

21. The more I study for a language test, the more confused I get.

22. I don't feel pressure to prepare very well for language class.

23. I always feel that the other students speak the foreign language better than I do

24. I feel very self-conscious about speaking the foreign language in front of other students.

25. Language class moves so quickly $\mathrm{l}$ worry about getting left behind.

26. I feel more tense and nervous in my language class than in my other classes.

27. I get nervous and confused when I am speaking in my language class.

28. When I'm on my way to language class, I feel very sure and relaxed.

29. I get nervous when I don't understand every word the language teacher says.

30. I feel overwhelmed by the number of rules you have to learn to speak a foreign language.

31. I am afraid that the other students will laugh at me when I speak the foreign language.

32. I would probably feel comfortable around native speakers of the foreign language.

33. I get nervous when the language teacher asks questions that I haven't prepared in advance. 